\title{
Study of crotoxin on the induction of paralysis in extraocular muscle in animal model
}

\author{
Estudo da crotoxina na indução de paralisia da musculatura extraocular em modelo animal
}

\author{
Geraldo de Barros Ribeiro ${ }^{1}$, Henderson Celestino de Almeida², David Toledo Velarde ${ }^{3}$, Maria Lygia Vaz de Melo Sáa
}

\begin{abstract}
Purpose: Crotoxin is the major toxin of the venom of the South American rattlesnake Crotalus durissus terrificus, capable of causing a blockade of the neurotransmitters at the neuromuscular junction. The objective of this study was to appraise the action and effectiveness of the crotoxin induced paralysis of the extraocular muscle and to compare its effects with the botulinum toxin type A (BT-A).

Methods: The crotoxin, with LD50 of $1.5 \mu \mathrm{g}$, was injected into the superior rectus muscle in ten New Zealand rabbits. The concentration variance was 0.015 up to $150 \mu \mathrm{g}$ Two rabbits received 2 units of botulinum toxin type A for comparative analysis. The evaluation of the paralysis was performed using serial electromyography. After the functional recovery of the muscles, which occurred after two months, six rabbits were sacrificed for anatomopathology study.

Results: The animals did not show any evidence of systemic toxicity. Transitory ptosis was observed in almost every animal and remained up to fourteen days. These toxins caused immediate blockade of the electrical potentials. The recovery was gradual in the average of one month with regeneration signs evident on the electromyography. The paralysis effect of the crotoxin on the muscle was proportional to its concentration. The changes with $1.5 \mu \mathrm{g}$ crotoxin were similar to those produced by the botulinum toxin type A. The histopathology findings were localized to the site of the injection. No signs of muscle fiber's necrosis were seen in any sample. The alterations induced by crotoxin were also proportional to the concentration and similar to botulinum toxin type $A$ in concentration of $1.5 \mu \mathrm{g}$.

Conclusion: Crotoxin was able to induce transitory paralysis of the superior rectus muscle. This effect was characterized by reduction of action potentials and non-specific signs of fibrillation. Crotoxin, in concentration of $1.5 \mu \mathrm{g}$ was able to induce similar
\end{abstract} effects as botulinum toxin type $A$.

Keywords: Crotoxin/administration \& dosage; Crotalid venoms; Snakes; Botulinum toxins, type A/administration \& dosage; Cobra neurotoxin proteins; Ophthalmoplegia/chemically induced; Neuromuscular junction; Comparative study

\section{RESUMO}

Objetivo: A crotoxina é a principal toxina do veneno da cobra cascavel sul-americana Crotalus durissus terrificus e causa bloqueio da neurotransmissão na junção neuromuscular. O objetivo deste estudo foi avaliar a ação e aplicabilidade da crotoxina na indução de paralisia da musculatura extrínseca ocular, e comparar seus efeitos com os da toxina botulínica do tipo A (TB-A).

Métodos: A crotoxina, com DL50 de 1,5 $\mu \mathrm{g}$, foi aplicada no músculo reto superior direito de dez coelhos da raça neozelandesa, em concentrações que variaram de 0,015 $\mathrm{\mu g}$ a $150 \mu \mathrm{g}$. Em dois coelhos, utilizou-se 2 unidades de toxina botulínica do tipo A para análise comparativa. A avaliação da paralisia foi realizada através de eletromiografia seriada. Após a recuperação, que ocorreu em dois meses, seis coelhos foram sacrificados para estudo anátomopatológico.

Resultados: Os animais não apresentaram sinais de intoxicaçãosistêmica. Ptosepalpebral transitória foi observada em quase todos os animais e permaneceu por até 14 dias. As toxinas causaram um bloqueio imediato da captação dos potenciais elétricos. A recuperação foi gradativa no período aproximado de um mês, observando-se sinais evidentes de regeneração no registro eletromiográfico. Os efeitos da crotoxina na paralização do músculo injetado foram proporcionais à concentração. A crotoxina, na concentração de 1,5 $\mathrm{\mu g}$, induziu alterações semelhantes às da toxina botulínica do tipo A. Os achados anátomo-patológicos foram localizados somente na região em que se aplicou as toxinas, não havendo necrose de fibras musculares em nenhuma amostra analisada. As alterações causadas pela crotoxina também foram proporcionais à concentração utilizada esimilares a toxina botulínica do tipo A na concentração de 1,5 $\mu \mathrm{g}$.

Conclusão: A crotoxina foi capaz de induzir paralisia transitória do músculo reto superior. Este efeito foi caracterizado pela redução na amplitude dos potenciais de ação e sinais inespecíficos de fibrilação. Observou-se que a ação da crotoxina, em concentração de 1,5 $\mu \mathrm{g}$, proporcionou efeito semelhante ao da toxina botulínica do tipo A.

Descritores: Crotoxina/administração e dosagem; Venenos de crotalídeos; Serpentes; Toxinas botulínicas tipo Aladministração e dosagem; Proteínas neurotóxicas de elapídeos; Oftalmolplegia/induzido quimicamente; Junção neuromuscular; Estudo comparativo

\section{INTRODUCTION}

Crotoxin is a b-neurotoxin, isolated from the poison of South American rattlesnake Crotalus durissus terrificus ${ }^{(1)}$. This toxin is a noncovalent oligomer, formed by two subunits: one acid and the other basic. The latter has phospholipase A2 activity and is neurotoxic, while the acid subunit is enzymatically and pharmacologically inactive, but it highly increases the toxicity of the basic subunit ${ }^{(2,3)}$. The acid subunit acts as a helper to the basic subunit, giving it specificity and increasing its stability. Crotoxin has molecular weight of $23.5 \mathrm{KDa}$. Its basic subunit has molecular weight of $14.3 \mathrm{KDa}$ and isoelectric point 8.9. It is formed by a single polypeptide branch with 123 amino acids. The acid subunit has molecular weight of $9.2 \mathrm{KDa}$ and isoelectric point 3.8, and it is formed by three polypeptides $(a, b, j)$ linked by seven disulfide bridges ${ }^{(3-5)}$. Both crotoxin subunits behave in a synergic manner, but dissociate when they interact with synaptic membranes. The basic portion remains attached to the membrane, while the acid portion is released into solution. The binding of the basic portion to synaptic membranes is not specific, and it can also bind to other membranes, while the acid portion does not attach. While in association to the basic portion, the acid subunit enhances its pharmacological action,
Submitted for publication: October 11, 2011

Accepted for publication: August 12, 2012

Study carried out at Strabismus Clinic at São Geraldo Hospital of Universidade Federal de Minas Gerais - UFMG - Belo Horizonte (MG) - Brazil

Physician, Strabismus Service, Universidade Federal de Minas Gerais - UFMG - Belo Horizonte (MG) - Brazil.

2 Teacher, Universidade Federal de Minas Gerais - UFMG - Belo Horizonte (MG) - Brazil.

${ }^{3}$ Biochemist, Hospital Foundation of Minas Gerais State - Fhemig - Belo Horizonte (MG) - Brazil.

${ }^{4}$ Physician, Institute of Clinical Neurophysiology of Minas Gerais, Belo Horizonte (MG) - Brazil.
Funding: No specific financial support was available for this study.

Disclosure of potential conflicts of interest: G.B.Ribeiro, inventor in patent UFMG (Universidade Federal de Minas Gerais) involving the use of crotoxin in humans; H.C.Almeida, inventor in patent UFMG (Universidade Federal de Minas Gerais) involving the use of crotoxin in humans; D.T.Velarde, inventor in patent UFMG (Universidade Federal de Minas Gerais) involving the use of crotoxin in humans; M.L.V.M.Sá, None.

Correspondence address: Geraldo de Barros Ribeiro, Av. Silviano Brandão, 1600 - Belo Horizonte MG - 30015-015 - Brazil - E-mail: gbarrosribeiro@gmail.com 
by significantly reducing the non-specific binding ${ }^{(3-5)}$. Crotoxin blocks the release of neurotransmitter at the presynaptic motor end-plate ${ }^{(6)}$.

Based on the crotoxin effect as a neuromuscular blocker, we decided to verify the possibility of using it to induce extraocular muscle paralysis in rabbits. The objectives of this study were: to evaluate the capacity of crotoxin to induce extraocular muscle paralysis in rabbits, analyze the duration of extraocular muscle paralysis induced by crotoxin; observe the duration and possible side effects of crotoxin at different concentrations through electromyography and anatomopathology exams, and finally compare crotoxin to botulinum toxin type A (BT-A).

\section{METHODS}

All procedures were conducted according to Brazilian Law no 6.638, May 1979. This law established regulations for the scientificdidactic practices of animal vivisection. It foresees that research should be realized always in a manner that does not cause any suffering to animals involved.

In this study, 12 new-Zealand rabbits were used, with average weight of $2.5 \mathrm{~kg}$. Rabbits were divided in 6 groups, with 2 rabbits in each group. Crotoxin dose initially used was based on the comparison of minimum lethal dose (LD50) of crotoxin and botulinum toxin type $\mathrm{A}$ in mice ${ }^{(1)}$.

Crotoxin used had a LD50 of $1.5 \mu \mathrm{g}$. Toxicity was determined by minimum lethal dose in 50\% of injected animals (LD50), using conventional Swiss mice, with weights from 18 to $22 \mathrm{~g}$.

Based on these calculations, it was decided to use different concentrations of crotoxin. Doses ranged from one hundred times smaller to one hundred times larger than the estimated DL50 of crotoxin.

One group received 2 units of botulinum toxin type $A$ (Botox ${ }^{\circledR}$ ).

Crotoxin and botulinum toxin type A were injected into the right superior rectus muscle of each rabbit, with an insulin syringe (Unijet, Plascalp Produtos Cirúrgicos Ltda., Feira de Santana, BA). The best place for injection was evaluated through electromyography.

Injection was done after instillation of $0.5 \%$ proximetacaine chloride anesthesic eye drop (Anestalcon ${ }^{\circledR}$-Alcon Laboratórios do Brasil, São Paulo, SP) and under direct visualization of the superior rectus muscle. Needle was introduced transconjunctivally and inserted into the muscle. Injection was made into superior rectus muscle $4 \mathrm{~mm}$ behind to the muscle insertion. Injected volume was $100 \mu \mathrm{l}$, except in rabbit no 12 , which received a volume of $50 \mu \mathrm{l}$. Solution applied in rabbit no 12 contained a concentration of $150 \mu \mathrm{g}$ in $100 \mu$ l: that means this rabbit received half the dose of rabbit no 11 .

The dose applied in each rabbit was:

Group I > Rabbits 1 and $2>0.015 \mu \mathrm{g}$ crotoxin

Group II > Rabbits 3 and $4>0.15 \mu \mathrm{g}$ crotoxin

Group III > Rabbits 5 and $6>1.5 \mu \mathrm{g}$ crotoxin

Group IV $>$ Rabbits 7 and $8>2$ of botulinum toxin type $A$ (BT-A $\left(\right.$ Botox $\left.^{\circledR}\right)$

Group $V>$ Rabbits 9 and $10>15 \mu$ crotoxin

Group VI > Rabbits 11 and $12>150 \mu \mathrm{g}$ crotoxin and $75 \mu \mathrm{g}$ crotoxin (respectively)

Rabbits were accompanied daily in the first week, watching for local and systemic side effects. Analysis of possible systemic side effects was done through observation of animal behavior. Laboratory testing to evaluate liver and kidney functions were not done. Afterwards, observation of animals was done twice a week until the end of the experiment. The evaluation of toxin effects was done through electromyography exams, and was done 2, 9, 16, 23 and 60 days after the injections. After the last electromyographic exam, one animal of each group was sacrificed for anatomopathology studies.

Electromyographic exams were done in the Institute of Clinical Neurophysiology of Minas Gerais, in Belo Horizonte. Animals received
3 drops of $0.5 \%$ proximetacaine chloride eye drop (Anestalcon ${ }^{\circledR}$ Alcon Laboratórios do Brasil, São Paulo, SP, Brasil) before the exam.

Electromyograph used was a Neuropack Four Mini Evoked Potential Measuring System MEB-5304K (Nihon Kohden, Tokio, Japan). A concentric bipolar electrode was used, with platinum central wire and stainless steel cannula. Length of electrode was $37 \mathrm{~mm}$; needle had $0.46 \mathrm{~mm}$ diameter, and a record area of $0.07 \mathrm{~mm}$ (Teca Corporation, catalogue number 53156, New York, USA). One hook-and-loop fastener tape (Teca Corporation, catalogue number GE-V, New York, USA), soaked in saline solution, was put around the ears of the rabbits for grounding the system.

Animals were sacrificed through intracardiac injection of $0.75 \%$ bupivacaine hydrochloride (Cristália Produtos Químicos Farmacêuticos Ltda., Itapira, SP, Brasil) after the last electromyographic exam. The right orbit of odd numbered rabbits, each one representing one group studied, was carefully exenterated and processed for histopathology exams.

Crotoxin used in this research was given by Immunobiological Division of Ezequiel Dias Foundation of Belo Horizonte - MG (FUNED). Crotoxin was obtained in its pure form and after lyophilization, was dissolved in saline buffer and afterwards its toxicity was evaluated through LD50 testing in mice. Toxicity of this solution was determined through LD50 testing in mice with 18 to 22 grams, intraperitoneally. Male and female mice were used, in groups of 8 animals per dose, with reading after 48 hours.

\section{RESULTS}

Rabbits tolerated well the experiment, not showing any behavior alteration after the injection of both toxins. One day after the toxins injection, only rabbit 4 did not have blepharoptosis; the other animals had discrete ptosis, which lasted for two days in rabbits 1, 2, 3, 5 and 6 , and seven days in rabbits 7,11 and 12. Rabbit 8 had the longest duration of ptosis: fourteen days. Conjunctival hyperemia on the site of injection was discrete in rabbits 1, 2, 3, 4, 7 and 8, lasting less than 48 hours and moderate in rabbits 5 and 6 , gradually improving in seven days. Rabbit 11 had the strongest reaction: besides conjunctival reaction, there was corneal edema, which improved after 14 days, but also produced permanent leukoma in the affected cornea. This lesion may have no relation to the application, because its location was distant from the area of injection.

\section{RESULTS OF ELECTROMYOGRAPHY}

Electromyographic (EMG) exams in superior recti muscles of all animals were normal before the injections, and they were repeated with 2, 9, 16, 23 and 58 days.

Results are divided in four tables according to days of follow-up (Tables 1 to 4).

At the fifty-eighth day of follow-up, the electromyography records were practically normal in all animals.

\section{RESUltS OF ANATOMO-PATHOLOGY STUDY}

The right orbit of six rabbits, one from each group, was exenterated for histological study 70 days after the injection of crotoxin or botulinum toxin type A. In all groups, alterations found in the superior rectus muscle were located 4 to $5 \mathrm{~mm}$ posterior to the scleral muscle insertion and observed only at the site of injection.

In group I (0.015 $\mathrm{\mu g}$ crotoxin), there was a discrete endomysial fibrosis on the injected area, the remaining muscle being normal. In group II ( $0.15 \mu \mathrm{g}$ crotoxin), endomysial fibrosis slightly more evident than in group I. In group III (1.5 $\mu$ g crotoxin), more evident local lesions as: discrete chronic inflammation, characterized by discrete lymphocytic mononuclear histiocytic infiltrate, myophagocytosis and edema with endomysial fibrosis, fibers with degenerative phenomena (vacuolated) and signs of muscle fibers regeneration (centralization of nuclei) (Figure 3). 
Table 1. EMG with two days of follow-up

\begin{tabular}{|c|c|c|}
\hline \multicolumn{3}{|c|}{ Results of electromyographic exams } \\
\hline Group 1 & $0.015 \mu \mathrm{g}$ crotoxin & $\begin{array}{l}\text { There were not any observable signs of irritability of neuromuscular membrane. } \\
\text { Observed contraction potentials had normal amplitudeand duration, with no significantalterations in fiber recruitment, which was only incomplete. }\end{array}$ \\
\hline Group II & $0.15 \mu \mathrm{g}$ crotoxin & Although potentials were under expected limits, the amplitudes were smaller when compared to potentials of the smaller dose. \\
\hline Group III & $1.5 \mu \mathrm{g}$ crotoxin & $\begin{array}{l}\text { Although the signs of membrane irritability were not present, potentials obtained were rare and of diminished amplitude. Findings sug- } \\
\text { gested a blockade of conduction between fibers. }\end{array}$ \\
\hline Group IV & $2 \cup B T-A$ & $\begin{array}{l}\text { There were signs of irritability of neuromuscular sheaths at rest due to blockade of neuromuscular joint conduction. There was no response } \\
\text { of fibers and no evidence of contraction of motor units. The presence of fibrillation potentials could indicate a functional denervation. }\end{array}$ \\
\hline Group V & $15 \mu \mathrm{g}$ crotoxin & $\begin{array}{l}\text { No signs of membrane irritability, but the rare potentials detected were of low amplitude, as if fibers were destroyed or blocked to stimulus } \\
\text { response. }\end{array}$ \\
\hline Group VI & $\begin{array}{l}150 \mu \mathrm{g} \text { crotoxin } \\
75 \mu \mathrm{g} \text { crotoxin }\end{array}$ & There was a complete silence in electromyography records. \\
\hline
\end{tabular}

Table 2. EMG with nine days of follow-up

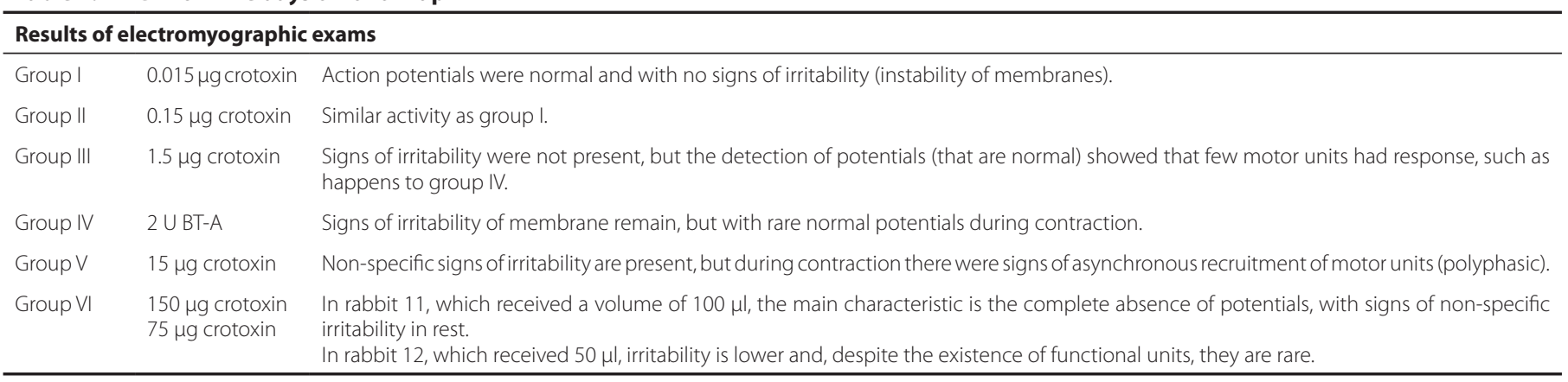

Table 3. EMG with sixteen days of follow-up

\begin{tabular}{|c|c|c|}
\hline \multicolumn{3}{|c|}{ Results of electromyographic exams } \\
\hline Group 1 & $0.015 \mu \mathrm{g}$ crotoxin & Action potentials were normal. \\
\hline Group II & $0.15 \mu \mathrm{g}$ crotoxin & Similar activity as group I. \\
\hline Group III & $1.5 \mu \mathrm{g}$ crotoxin & Normal potentials during contraction, with more intense signs of irritability. \\
\hline Group IV & $2 \cup B T-A$ & $\begin{array}{l}\text { Signs of neuromuscular irritability were more intense, and potentials with normal amplitude and duration during contraction, associated } \\
\text { to long polyphasic potentials, characterizing asynchronous recruitment process, typical of recent reinnervation. Although the pattern of } \\
\text { recruitment was not normal, there was no rarefaction in response. }\end{array}$ \\
\hline Group V & $15 \mu \mathrm{g}$ crotoxin & Normal potentials, with signs of recent reinnervation. \\
\hline Group VI & $\begin{array}{l}150 \mu \mathrm{g} \text { crotoxin } \\
75 \mu \mathrm{g} \text { crotoxin }\end{array}$ & Normal potentials during contraction, but the number of motor units was reduced. \\
\hline
\end{tabular}

Table 4. EMG with twenty days of follow-up

\begin{tabular}{|c|c|c|}
\hline \multicolumn{3}{|c|}{ Results of electromyographic exams } \\
\hline Group | & $0.015 \mu \mathrm{g}$ crotoxin & Normal potentials and recruitment. \\
\hline Group ॥ & $0.15 \mu \mathrm{g}$ crotoxin & $\begin{array}{l}\text { Signs of irritability were not present and, during contraction, units were in normal quantity, but there were signs of asynchronous recruitment, } \\
\text { typical of reinnervation. }\end{array}$ \\
\hline Group III & $1.5 \mu \mathrm{g}$ crotoxin & Some non-specific signs of irritability remained, and present motor units were reduced (figure 1) \\
\hline Group IV & $2 \cup B T-A$ & $\begin{array}{l}\text { Signs of irritability were not present, and motor units presented normal amplitude and duration during contraction. The pattern of inter- } \\
\text { ference was still incomplete, but there were not long duration polyphasics (asynchrony), which indicated that the process of regeneration } \\
\text { was complete (Figure 2). }\end{array}$ \\
\hline Group V & $15 \mu \mathrm{g}$ crotoxin & Normal potentials during contraction, with intense signs of irritability and signs of asynchronous recruitment. \\
\hline Group VI & $\begin{array}{l}150 \mu \mathrm{g} \text { crotoxin } \\
75 \mu \mathrm{g} \text { crotoxin }\end{array}$ & $\begin{array}{l}\text { Signs of neuromuscular irritability associated with long duration polyphasic potentials, which indicated process of asynchronous recruitment, } \\
\text { typical of recent reinnervation. }\end{array}$ \\
\hline
\end{tabular}


In group IV (2 U BT-A), anatomo-pathology alterations were similar to those found in group III (Figure 4).

In group $V(15 \mu$ g crotoxin), degenerated fibers (vacuolated), with loss of striation and marked endomysial fibrosis. Muscle fibers with signs of degeneration.

In group VI (150 and $75 \mu \mathrm{g}$ crotoxin), more marked signs of muscle fiber degeneration, such as myophagocytosis, discrete endomysial fibrosis and chronic inflammatory infiltrate, and also muscle fibers with signs of degeneration (central nucleus). There was no muscle necrosis.

\section{DISCUSSION}

Most of our current knowledge about various human pathologies was experimentally discovered in animals. It is necessary, naturally, to take care when extrapolating the analysis of results with animals to human beings.

In our study, the rabbit, despite not having binocularity - vision axis are not parallel -, was useful for presenting extraocular muscles well developed, especially the superior rectus, and also because it is an animal of easy handling. Using only anesthetic drops, we were able to perform electromyography of the superior rectus muscle to evaluate the effects of the injected toxins and its subsequent recovery.

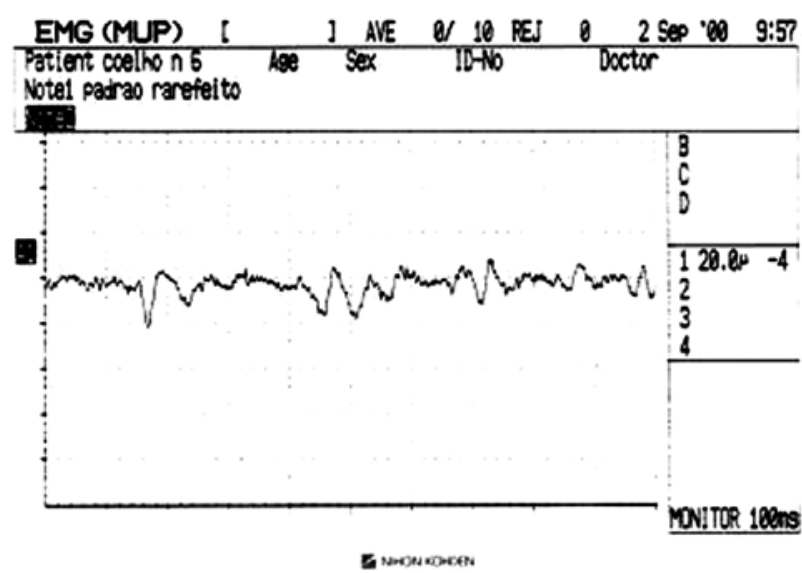

Figure 1. EMG of rabbit 6, twenty-three days after the injection of $1.5 \mu \mathrm{g}$ crotoxin.

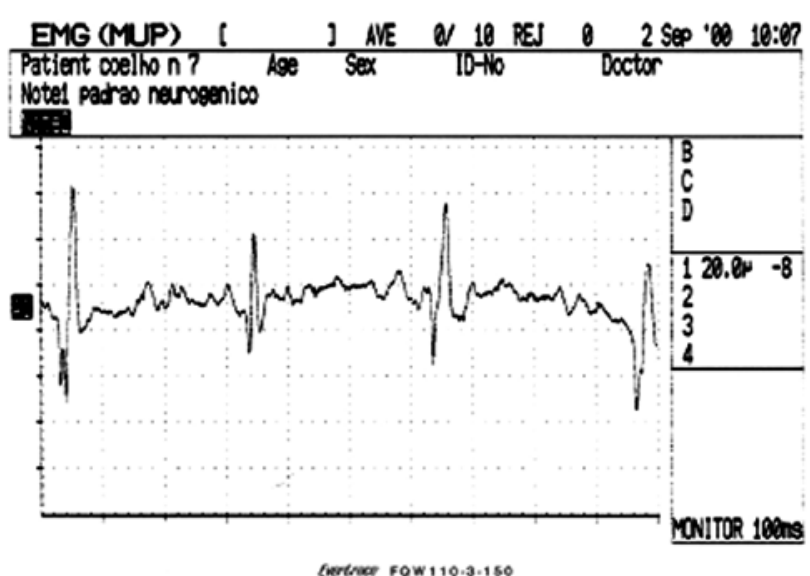

Figure 2. EMG of rabbit 7, twenty-three days after the injection of $2 \mathrm{U}$ botulinum toxin type $A$.
The injection of toxins was well tolerated by rabbits, without signs of prostration or changes in feeding behavior. The main local side effect observed was ptosis, which occurred in eleven of twelve rabbits, the day after the injection. However, the ptosis was discrete and improved after two days in rabbits 1,2, 3, 5 and 6, after seven days in rabbits 7,11 and 12 and remained for two weeks in rabbit 8, which received $2 \mathrm{U}$ of $\mathrm{BT}$-A. Ptosis observed in monkeys in the first research with botulinum toxin lasted up to six weeks ${ }^{(7)}$. Dosing used for this animal was higher than used in our study. Besides, they injected a volume up to $500 \mu \mathrm{l}$, which easily diffuse to adjacent tissues. Animals receiving A-bungarotoxin (snake poison) on the same experiment showed ptosis, which improved after three days ${ }^{(7)}$.

Conjunctival hyperemia observed after the injection was discrete, and improved after 48 hours in rabbits 1, 2, 3 and 4 (which were submitted to lower doses of crotoxin), and in rabbits 7 and 8 (which received 2 units of botulinum toxin type A). Rabbits 5 and 6 that had injections of $1.5 \mu \mathrm{g}$ crotoxin, showed moderate hyperemia, which gradually improved, in seven days. Scott et al., in 1973(7), had also observed a discrete local reaction in animals submitted to injection of A-bungarotoxin and botulinum toxin, which improved after one day. A more marked local reaction, with hyperemia and purulent secretion, was observed in rabbits 9, 10, 11 and 12, but improved spontaneously, without any topic medication, in approximately one

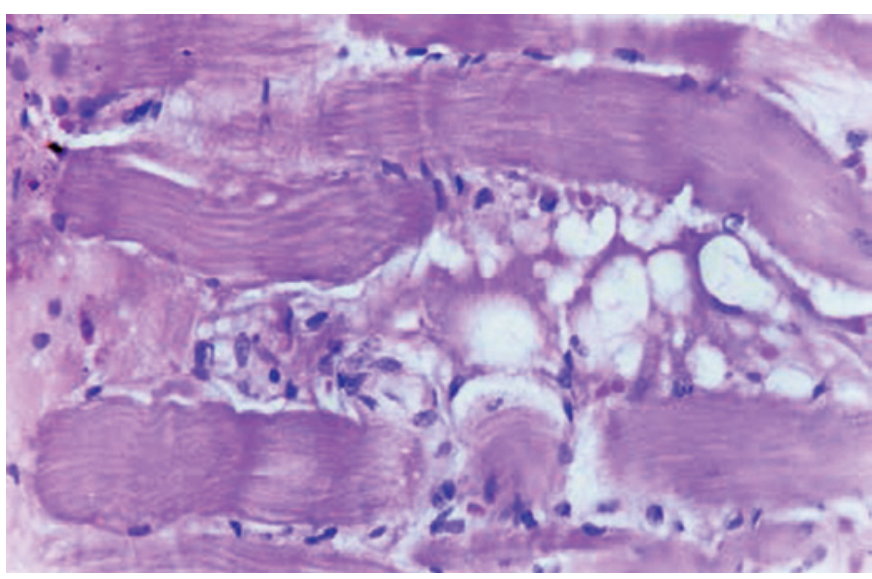

Figure 3. Fibers with degenerative phenomena (vacuolated) and signs of muscle fibers regeneration (centralization of nuclei) (magnification of 400X, stained with hematoxylin-eosin) in group III (1.5 $\mu \mathrm{g}$ crotoxin).

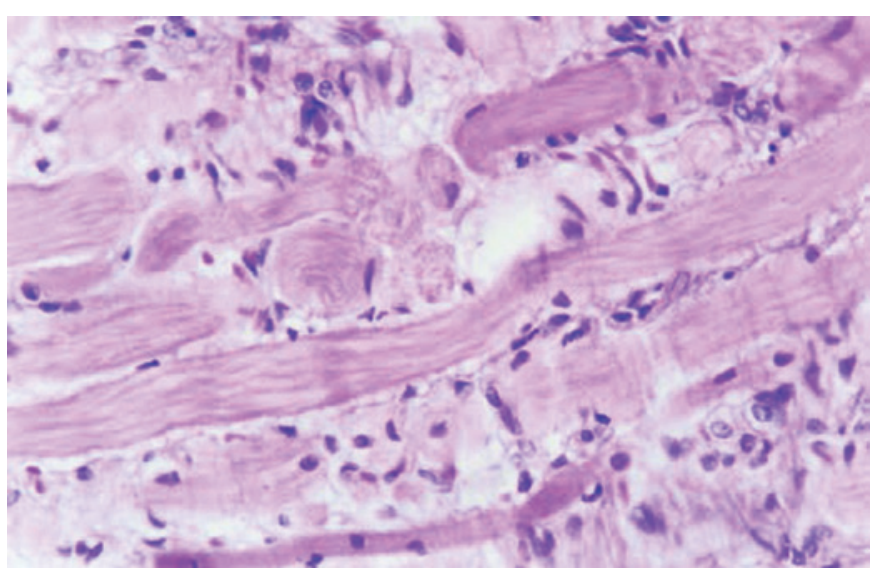

Figure 4. Discrete degenerated muscle fibers (vacuolated), edema, endomysial fibrosis and mononuclear infiltrate (magnification of $400 \mathrm{X}$, stained with hematoxylin-eosin) in group IV ( 2 U BT-A). 
week. Rabbit 11, besides conjunctival reaction, had also corneal leukoma, which persisted until the end of the experiment.

There are still some doubts about the mechanism of action of crotoxin in inducing the neuromuscular blockade. The process of transmission of information in synapses involves several stages. In a general way, stimulus activate an action potential that leads to alteration of ions flux, due to the opening and/or closing of ionic channels, ending with the release of neurotransmitters, which were stored in synaptic vesicles.

Several proteins located in the plasmatic membrane of nervous terminal or in the membrane of synaptic vesicle, or even free in the neuron cytoplasm, are involved in the process of neurotransmitter release. They act on recycling, translocation, anchorage and fusion of synaptic vesicles to cell membrane. Proteins that are, so far, known for participating in this process, are: syntaxin, synaptosomal-associated protein 25 (SNAP-25), neurexin, voltage sensitive calcium channels, PKC, N-ethylmaleimide-sensitive factor (NSF), soluble NSF attachment proteins (SNAPs) a, b, g, kinase C substrate, myristoylated alanine-rich (MARCKS) and growth associated protein (GAP-43), synapsins (la, Ib, Ila, IIb and II a), synaptobrevin, synaptophysin, synaptotagmin, CaMK I and II, dinamin, rab, GTP-binding proteins and rabphilin ${ }^{(8,9)}$.

Botulinum toxin type A targets synaptosomal-associated protein 25 (SNAP-25), of molecular weight 25KDa. Other types of botulinum toxin attach themselves to different membrane proteins or to synaptic vesicle ${ }^{(8,9)}$.

Crotoxin has phospholipase activity $A_{2}\left(P L A_{2}\right)$, necessary for its toxic effect. The substitution of $\mathrm{Ca}^{2+}$ ions, essential to phospolipase activity, for $\mathrm{Sr}^{2+}$, inhibits the toxic effect of crotoxin ${ }^{(10-12)}$. According to these authors, toxins would bind to cell membrane, dependent on calcium and, afterwards, would be endocyted into synaptic vesicles. Due to its phospholipase action on the vesicle membrane, they would irreversibly block vesicular endocytosis. Crotoxin also interferes in calcium and potassium channels, and this could reduce the acetylcholine release in the neuromuscular junction ${ }^{(13)}$. It alters also protein phosphorylation in the neuromuscular junction ${ }^{(14)}$.

In this study, evaluation of paralysis or paresis of superior rectus muscles after injection of crotoxin and BT-A was done through electromyography. Extrinsic ocular muscles of rabbits are striated. This type of muscle is functionally formed of motor units in which axons of individual motor cells innerve several muscle fibers. Motor units are the smallest functional units of the locomotor apparatus. Information on the function of these units is obtained, mainly, from the use of electromyography. The sum of several action potentials of many motor-end plates forms the action potential of the muscle, which originates in the motor-end plates and is initiated from an afferent nervous impulse to neuromuscular joint. This nervous impulse is spread all over the muscle fibers, stimulating contraction. The intensity of muscle contraction depends, partially, on the number of motor units that are being activated (recruitment) and, partially, on the frequency neurons are sending impulses to muscle fibers. In lesions of peripheral nerve, electromyography can be used in a previous stage than any other method to identify paralysis and record if regeneration is happening accordingly. If peripheral motor neurons that supply a muscle are completed destroyed, lesion will be partial, proportional to the number of affected cells. In denervated muscles, that lost their nerve supply, there are still some action potentials that can be observed on electromyography, and these are called fibrillation potentials, which seem to originate in isolated muscle fibers that lost their innervations. The origin of fibrillation is not completely understood, but some authors say that it is due to a "sensitization" of the muscle portion of the motor-end plate after denervation. The absence of the neurotransmitter can stimulate the muscle fibers to respond to a very small quantity of acetylcholine present in blood stream.

Electromyographic findings demonstrated that crotoxin caused a reversible paralysis of muscular activity, being proportional to the dose injected, according to other authors ${ }^{(13)}$. Reduction in action potentials was observed mainly in crotoxin concentrations greater than $1.5 \mu \mathrm{g}$. Recovery of paralysis was gradual, and at the end of two months of follow-up, electromyographic records were almost normal. BT-A injected also caused a reversible paralysis. Action potentials of muscles injected with BT-A had its recovery starting after nine days, and were close to normality after two months. That shows that paralysis induced by known concentrations of crotoxin had similar duration than BT-A.

High concentrations of crotoxin have myotoxic effect ${ }^{(3,15)}$. Morphologic alterations observed in mice, through electron microscopy, show that, in high doses, crotoxin affects nerve terminals, skeletal muscle and the axons. These effects were also observed with only the injection of PLA, subunit from crotoxin, what was not demonstrated with the other subunit. First structures that are affected by crotoxin are: sarcolemma, mitochondria and sarcoplasmic reticulum ${ }^{(16,17)}$. In 1984, it was evidentiated that the beginning of myonecrosis caused by crotoxin was provoked by a progressive loss of sarcolemma integrity, due to hydrolysis of phospholipid component. Regeneration of muscle fibers was fast ${ }^{(18)}$.

In our experiment, one animal from each group was sacrificed for anatomopathology studies. Histological alterations found were proportional to crotoxin concentration, and located only on the site of injection. There was no muscle fiber necrosis in any specimen. At lower concentrations (0.015 and $0.15 \mu \mathrm{g}$ ), it was observed only discrete endomysial fibrosis and, in some regions, mononuclear infiltrate. At concentration of $1.5 \mu \mathrm{g}$ of crotoxin, inflammatory process was also discrete, however, it was possible to observe signs of myophagocytosis, vacuolated fibers (degenerative sign) and fibers with central nucleus (regeneration sign). These alterations were similar to those found in rabbits that received BT-A. Some studies show that the injection of botulinum toxin type A causes muscle alterations, proportional to toxin concentration ${ }^{(19)}$. Similarly to studies with crotoxin, histological alterations caused by botulinum toxin type $A$ were reversible ${ }^{(20)}$. Changes observed in groups $V$ and $\mathrm{Vl}$, that received crotoxin at concentrations of $15 \mu \mathrm{g}$ and $150 \mu \mathrm{g}$, respectively, were more marked than the changes observed in other groups, and it is even more evident in the group of the highest concentration. Signs of degenerated fibers (vacuolated), loss of striation and endomysial fibrosis were more marked. Signs of regeneration of muscle fibers (characterized by the presence of central nucleus) were also evident.

\section{CONCLUSIONS}

Muscle paralysis induced by crotoxin injection could be demonstrated with the help of electromyography. At concentration of $1.5 \mu \mathrm{g}$, crotoxin caused similar effects to botulinum toxin type A, showing only discrete local histological alterations. Based on these findings, we believe that the pharmacological activity of crotoxin can be useful to treat pathologies that have been receiving botulinum toxin with success. Clinical studies in human beings are necessary to corroborate crotoxin applicability in several areas of medicine.

\section{REFERENCES}

1. Rubsamen K, Breithaupt $\mathrm{H}$, Habermann E. Biochemistry and pharmacology of the crotoxin complex. I. Subfractionation and recombination of the crotoxin complex. Naunyn-Schimiedebergs Arch Pharmak. 1972;270(3):274-88.

2. Horst J, Hendon RA, Frankael-Conrat H. The ative components of crotoxin. Biochem Biophy Res Commun. 1972;46(3):1042-7.

3. Haberman E, Breithaupt H. Mini-review: the crotoxin complex an example of biochemical and pharmacological protein complementation. Toxicon. 1978:16(1):19-30

4. Bon C, Changeux JP, Jeng TW, Frankael-Conrat H. Post-synaptic effects of crotoxin and of its isolated subunits. Eur J Biochem. 1979;99(3):471-81.

5. Tzeng MC, Hseu MJ, Yang JH, Guillory RG. Specific binding of three neurotoxins with phospholipase A2 activity to synaptosomal membranes preparations from the guinea pig brain. J Protein Chem. 1986;5:221-8. 
6. De Lima ME, Diniz CR. Crotoxin inhibits the release of acetylcholine induced by Tityus serrulatus scorpion venom. Toxicon. 1985;23(4):588.

7. Scott AB, Rosenbaum A, Collins CC. Pharmacologic weakening of extraocular muscles. Invest Ophthalmol Vis Sci. 1973;12(12):924-7.

8. Bajjalieh SM, Scheller RH. Synaptic vesicle and proteins exocytosis. In: Starne L, Greengard P, Grillner SE, Hokfelt TG, Ottoson DR. Molecular and cellular mechanisms of neurotransmitter release. New York: Raven Press; 1994. p.59-79.

9. Coffield JA, Considine RV, Simpson LL. The site and mechanism of action of botulinum neurotoxin. In: Jankovic J, Halle M, editors. Therapy with botulinum neurotoxin. New York: Marcel Dekker, 1994. p.3-13.

10. Breithaupt H. Neurotoxic and myotoxic effects of crotalus phospholipase A and its complex with crotapotin. Naunyn-Schmideberg's Arch Pharmacol. 1976;292(3):271-8.

11. Simpson LL, Lautenslager GT, Kaiser II, Middlebrook JL. Identification of the site at which phospholipase A2 neurotoxins localize to produce their neuromuscular blocking effects. Toxicon. 1993;31(1):13-26.

12. Montecucco C, Rosseto O. How do presynaptic PLA2 neurotoxins block nerve terminals? Trends Biochem Sci. 2000;25(6):266-70.

13. Araújo DA, Beirão PS. Effects of crotoxin on the action potential kinetics of frog skeletal muscle. Braz J Med Biol Res. 1993;26(10):1111-21.
14. Campos AC. Efeito da crotoxina na fosforilação de proteínas da fração sinaptosomal de córtex de rato [tese]. Belo Horizonte, Instituto de Ciências Biológicas, Universidade Federal de Minas Gerais; 2000.

15. Gopalakrishnakone P, Hawgood BJ. Morphological changes in murine nerve, neuromuscular junction and skeletal muscle induced by the crotoxin complex [proceedings]. J Physiol. 1979;291:5P-6P.

16. Harris JB, Johnson MA, Mac Donell CA. Muscle necrosis induced by some presynaptically active neurotoxins. In: Eaker D, Wadstrom T, editors. Natural toxins. , Oxford: Pergamon Press; 1980. p.569-78.

17. Howard BD. Presynaptic polypeptide neurotoxins. Trends Pharmac Sci. 1982 3:167.

18. Gopalakrishnakone P, Dempster DW, Hawgood BJ, Elder HY. Cellular and mitochondrial changes induced in the structure of murine skeletal muscle by crotoxin, a neurotoxic phospholipase A2 complex. Toxicon. 1984;22(1):85-98.

19. Borodic GE, Ferrantle R, Pearce LB, Smith K. Histologic assessment of dose related diffusion and muscle fiber response after therapeutic botulinum A toxin injections. Mov Disord. 1994;9(1):31-39.

20. Porter JD, Strebeck S, Capra NF. Botulinum induced changes in monkey eyelid muscle. Arch Ophthalmol. 1991;109(3):396-404. 